\title{
New Directions to the Global Century
}

Patti McGill Peterson

Council for International Exchange of Scholars

Institute of International Education

At the turn of our new century, prognostications of things in store for Americans abounded. Prominent among the predictions was the description of a much more interdependent world, one in which we would be linked by easier travel, lowered national borders and a surge of electronic communication. The importance of international cooperation and the growing significance of the United Nations and international peacekeeping figured significantly in this agenda. Anyone paying attention could not escape the central message: citizens of the United States were going to be part of a Global Century, in which isolation from international cross currents would be impossible, and for which it would be necessary to prepare future generations of Americans.

Some observers wondered if our institutions of higher education were well-positioned for the challenges of offering students an education that would prepare them to live and work in this new world of global togetherness. As voices in the chorus of concern, Philip Altbach and I co-authored an article that we titled, "Internationalize American Higher Education? Not Exactly." 1 We played provocateur to spoken and unspoken assumptions that America's institutions of higher education were poised to deliver international education of the kind and quality necessary to address a new buzzword - internationalism. Looking at the rhetoric and realities, we challenged American institutions to show a more coherent, strategic approach to making the buzzword operational. There were signs all around us that all was not well with our international education agenda, for example the percentage of American students studying abroad and the number of faculty engaged in international dimensions of research and teaching.

Those concerns notwithstanding, there has been a noticeable and commendable effort in recent years on the part of a number of colleges and 
Patti McGill Peterson

universities to develop more coherent approaches to their goal of becoming more globally focused institutions. More students are studying abroad (although still a very small percentage), and the range of their study abroad opportunities has widened considerably. While U.S. faculty may not be as engaged internationally as some of their counterparts in other countries, applications for the Fulbright Scholar Program have increased and more institutions report international experience as valuable for faculty, regardless of their academic disciplines. The monolingual profile of our graduates still needs to be addressed, but a variety of institutions are beginning to look closely at their undergraduate curricula and to build in a broader cross-cultural perspective. Some institutions are introducing global studies tracks. There is reason to be optimistic.

\section{Winds of Change}

Just as we seemed to have a wind in our international sail, the world turned and it became a less hospitable place to practice our internationalism. Americans find themselves in a very different place in 2003 than in 2000. Within the space of three years, a set of contradictory messages has emerged and now confounds the efforts underway to make our colleges and universities a greater part of the world at large. We are closely tied to other countries and people of the world; however, there are now more perceived dangers in that interdependence. Ease of crossing national borders was a welcome sign of internationalism at work in the pre-9/11 world, but now there is a perception of a dark side to the lowering those borders. Acts of terror, the residual of war in the Middle East and the outbreak of SARS have cast our internationalism in a new and challenging context.

We might ask ourselves, are we living not only in an era of national "Code Orange" alert, but also in an era of a global Code Orange? Developments in two areas evoke this question. One area on the home front relates to how we welcome visitors to our country, particularly visiting students and scholars. The other area relates to how Americans are regarded abroad and its implications for our international education goals and even for the pragmatic acts of traveling to, and living in countries beyond our shores.

Many international educators have advocated a more positive inclusion of foreign students and scholars in the lives of our institutions. The 
Frontiers: The Interdisciplinary Journal of Study Abroad

active participation of visiting scholars and students in our institutional goal of becoming more deeply and coherently internationalized centers of learning has always warranted thoughtful consideration. Now there is a greater challenge in simply having them feel welcome in our country. Recent reports and articles point increasingly to the chilly receptions received by international visitors. A special report in the April 11, 2003 issue of The Chronicle of Higher Education was devoted to the topic. ${ }^{2}$ As noted in the report, tightened homeland security, while perhaps comforting in some sense, also is exacting a toll on the realization of international education goals. The possibility that visiting scholars and students will experience a cyber version of Ellis Island is a real one, and the impact on international education and exchange could be increasingly negative. The perception of international students and scholars being unwelcome in the United States is an issue that warrants our ongoing attention and concern.

International educators also need to consider how Americans may be greeted outside the United States and how this might collide with our internationalism. In the same issue of the Chronicle a headline read, "14 Indian Universities Vow to Boycott Programs Involving the United States or Britain." To read that faculty wished to refuse participation in American-sponsored government programs and even wanted to turn down U.S. scholarships and exchange programs on campuses which had once welcomed them, was disconcerting. American scholars are reporting a deepening chill in other countries also. Scholars from Latin America called for a boycott of the annual meeting of the Latin American Studies Association held in Dallas, Texas. An American colleague participating in a transatlantic dialogue program related what for him was a surprising outburst of anti-Americanism at a scholarly meeting in Brussels. An economist at the University of Natal in South Africa indicated that he was rethinking his sponsorship of American students who studied at his institution. Are these isolated incidents? Or do they represent the beginning of something larger and more challenging to our interests in sending students and faculty abroad?

One thing, however, is certain. There is now more outspoken antiAmericanism in many places around the world, and not just among Arab populations in the Middle East. Of concern are signs that this may be carried forward by new generations in a variety of countries with which international educators wish to have exchanges. A study conducted by Professors Margaret and Melvin DeFleur in the College of 
Patti McGill Peterson

Communication at Boston University (B.U.) illustrates a potential source of these worries. In a survey of the attitudes and beliefs of high school students in twelve countries (Argentina, Bahrain, China, Dominican Republic, Italy, Mexico, Nigeria, Pakistan, Saudi-Arabia, Spain, South Korea, and Taiwan) only the Argentineans held generally favorable views of Americans. The respondents from other nations, while the scale varied from country to country, had consistently negative attitudes towards Americans. ${ }^{3}$

These attitudes may have been in formation for some time, but current circumstances have the potential to give them a new edge. The danger is that these views, held without much outward expression by teenagers in places such as those included in the B. U. survey, may be exacerbated and encouraged to the surface by the residual tensions of the war with Iraq, not just in the Arab world but in many places where U.S. students and faculty might participate in international exchange opportunities. Parents perennially worry about their children going for an extended time to a faraway place. Faculty members are frequently concerned about what living conditions will be like for them and their families in lesser-known countries. Growing anti-Americanism is not likely to abate these fears.

\section{At the Crossroads}

As American educators we find ourselves at a perplexing crossroads. How, in this climate of increasing uncertainty and sometimes outright antagonism, shall we pursue our goals of internationalism? As we consider the impediments to our international intentions, can we pursue our educational objectives as confidently as we prepared to do at the onset of the new century?

While I do not wish to underestimate the seriousness of the obstacles and challenges, the educational imperative of the $21^{\text {st }}$ century has not changed. Indeed, given the tensions in the world and the issues of international cooperation, the role of international education has become even more important. The pressing need was well stated in a Carnegie Foundation report:

Americans need to understand their relationship to the rest of the world is critical ... although the U.S. is now the world's preeminent military and economic power, and the reach of its 
Frontiers: The Interdisciplinary Journal of Study Abroad

political and popular culture is global, it cannot control events and remains vulnerable to faraway developments. Because of our global reach and the openness and diversity of our society, we are perhaps even more easily affected by international and global phenomena than small and remote nations. Nothing is therefore foreign to us even though we live and compete in a world of differences. Understanding our place in that world and the cultural, social, political and economic variations of which that world is comprised presents a tremendous challenge for education as we enter the twenty-first century. ${ }^{4}$

Our educational institutions need foreign students and scholars, myriad opportunities for students to study abroad, a worldly curriculum and institutional linkages that connect us to a wider global community of educators and a varied assortment of cultures. These are not frills but fundamental necessities for our viability as educational institutions in the $21^{\text {st }}$ century.

I would argue further that, in a Code Orange world, our country needs us to do all of these things and more to improve our international relations and to create bridges between citizens as a network for peace. Some might be concerned about the connections between educational internationalism and the international relations of the United States. It is important to draw a line between the official policies and diplomacy of the United States government and the kind of diplomacy that individual students and faculty invariably exercise when they study, teach and do research abroad. However, it is precisely this unofficial "soft diplomacy" that is profoundly important to the improvement of America's relationships with the rest of the world over the short and long term. It is the countervailing force needed to help citizens of other nations understand that Americans are not all alike and that we cannot be lumped into an easy stereotype.

\section{Fulbright: A Model for Multiple Outcomes}

I have had the privilege over the past five years of observing firsthand how the interests of international education and public diplomacy can converge in positive ways. The vehicle for this convergence has been 
Patti McGill Peterson

the Fulbright Scholar Program, which provides opportunities for U.S. faculty and professionals to teach and do research in approximately 140 countries around the world, including a number of predominately Muslim countries. In the spirit of exchange, it provides similar grants for visiting scholars and professionals to come to the United States.

The power of the program was in full evidence in the fall of 2002 when the Fulbright exchange between the United States and Japan celebrated its fiftieth anniversary. Highlighted in the celebration was testimony that mortal enemies in World War II could be brought together by the powerful magnet of education. One elderly Japanese scholar remarked that it would be unthinkable that the United States and Japan would ever again take up arms against one another. This, he noted, was not because of any military arsenal or nuclear deterrent but because of the deep respect each country had developed for the other and its citizens through years of international education and academic exchange that Fulbright had provided.

This outcome would have pleased the program's legislative sponsor, Senator William Fulbright, whose founding sentiments included not just the goal of mutual understanding but the hope that educational exchange would create a bulwark for a lasting peace among nations. The substance of his optimism was quoted often in the days following the tragedy of September 11, 2001:

Mankind's capacity for decent behavior seems to vary directly with our perception of others as individual human beings with human motives and feelings, whereas our capacity for barbarism seems related to our perception of an adversary in abstract terms. International educational exchange is the most significant current project designed to continue the process of humanizing mankind to the point that we can learn to live in peace. ${ }^{5}$

Fifty-six years after its founding, the Fulbright Program can claim the largest movement of students and scholars across the world that any nation has ever sponsored. The residual of good will left in its wake is documented frequently in many countries around the world. Also important to that good will is the fact that leaders of many other countries proclaim a familiarty with and a fondness for America and its people due to their experiences as Fulbright fellows and scholars.

Likewise, the presence of U.S. Fulbright students and scholars in 
distant places has had a cumulative positive effect. The pervasiveness of this kind of "people diplomacy" cannot be replicated by the official diplomacy of visiting heads of state. A survey conducted by SRI International that polled cohorts of Fulbright Scholars presents a compelling case for the convergence of individual, institutional and diplomatic benefits. The vast majority of those responding reported that they and their institutions benefited significantly from their Fulbright experiences. They documented their responses with such outcomes as revising their courses and teaching methods and adding new dimensions to their research. Many became more active in efforts to internationalize their institutions through more cross-disciplinary and cross-departmental collaboration. Some also became more interested in the presence of foreign students and faculty on their campuses and more involved in activities related to them.

They moved beyond campus-based activity to sustain the international relationships that they began during their Fulbright grants. Seventy-five percent continued to collaborate with colleagues from their host countries or institutions since completing their grants. Almost 70 percent have initiated professional exchanges for students or other faculty since completing their grants. Approximately 60 percent have revisited their host countries and institutions. Nearly 70 percent have been visited in the United States by colleagues or friends from their host institutions. ${ }^{6}$

While all these individual educational and institutional outcomes were evident, there was invariably a bonus outcome that redounded to the benefit of international relations. Scholars' responses indicated that deep reservoirs of good will were being formed by Fulbright exchange. This was summed up well by one of the scholars, "It is an antidote to prejudice and stereotypes that thrive amidst ignorance. And it forms people-to-people bonds that serve as vital bridges for communication and cooperation."

Fulbright Scholars are not required to take an oath of loyalty, to teach in certain ways or to teach particular ideas, but, nevertheless, understand that a major purpose of the program is to promote mutual international understanding and that, in this respect, they are ambassadors for the United States. They are a very diverse group of people with widely varying backgrounds who fulfill Senator Fulbright's best hopes for the program that bears his name. In doing so, they serve their own personal and professional enhancement, their college or university, as well as their country. These interests can converge without one holding the other hostage to any preconceived script. 
Patti McGill Peterson

I would be hard pressed to think of anything more fruitful for my country's educational institutions, as well as its international relationships, than the person-to-person diplomacy that is conveyed in international education and exchange programs. Whether it be governmentsponsored programs like Fulbright or programs supported directly by colleges and universities, they invariably bear extraordinary fruit.

This capacity was well illustrated by a report from a professor who had a Fulbright grant to teach bioethics at Bar-Ilan University in Israel. She was making a case against calls for an academic boycott of Israel. In arguing for keeping the doors open, she indicated that ten years earlier she had witnessed the chasm of misinformation across cultures when she was lecturing in Prague and staying at the home of a Czech colleague. She was astonished to learn that her friend believed that blacks and whites in the United States never attended the same schools, or lived in the same neighborhood. When the scholar explained that she lived in a mixed-race neighborhood in Cleveland and that one of her son's teachers was someone of a different race, her colleague was incredulous. The American scholar experienced a similar breakthrough during her recent Fulbright in Israel, only this time it was her own enlightenment. She discovered much to her astonishment and counter to information in the American press, that there was a vibrant peace movement in Israel. She witnessed firsthand how broad-based the call for peace was among Israelis, including orthodox Jews, and she was able to participate personally in that movement. While she had performed an academic mission in her host county, she also exercised a form of international citizenship that would have eluded her had association with Israeli universities been blocked.

\section{Staying on Course}

Keeping borders and institutions open should concern us all. The movement of people and ideas across the world is vital to our institutional goals and to our national welfare. The tightened network of policies intended to secure our borders and make our cities safe does not bespeak the kind of Global Century many of us had in mind as we celebrated the new millennium. Those of us committed to the agenda of creating more globally-focused institutions of higher education are now confronted with new obstacles and a less amenable environment for international 
Frontiers: The Interdisciplinary Journal of Study Abroad

exchange. Staying true to our course takes more time, persistence and basic faith in humankind.

In the face of all the impediments, the worst thing we could do is give up and recommend that everyone stay at home. I have found a wonderful example in the form of a new friend from the Middle East. He is a distinguished educator who holds undergraduate and advanced degrees from U.S. institutions. During a recent trip to the United States from Beirut, Lebanon, he was stopped and interrogated by the INS for a lengthy period of time. He described it as an unpleasant experience but quickly stated that he was thinking of ways to get his colleagues back home ready for the passage through U.S. borders so that they would not be discouraged from participating in the educational exchanges he is planning.

The changing and challenging context for international education and international relations will require the same kind of determination from American educators. The path to the Global Century turns out not to be as unencumbered as we may have once thought it would be. While the world has changed, our international education goals have not. The American scholar in Tel Aviv and the Lebanese scholar from Beirut light the way. ${ }^{7}$

\section{Notes}

${ }^{1}$ Philip G. Altbach and Patti McGill Peterson, "Internationalize American Higher Education? Not Exactly." Change 30 (July/August 1998):36-39.

${ }^{2}$ Special Report, The Chronicle of Higher Education 48 (April 11, 2003).

${ }^{3}$ Margaret H. \& Melvin L. DeFleur, The Next Generation's Image of Americans: Attitudes and Beliefs Held by Teenagers in Twelve Countries, a Preliminary Research Report. (Boston, MA: College of Communication, Boston University, 2003).

${ }^{4}$ Carol M. Barker, Education for International Understanding and Global Competence: Report of the Carnegie Corporation of New York. (New York, NY: Carnegie Corporation, 2000).

${ }^{5}$ William J.Fulbright, Remarks at the Fortieth Anniversary Observance of the Fulbright Program. (The Hague: The Netherlands, 1986).

${ }^{6}$ Office of Policy and Evaluation, Bureau of Educational and 
Patti McGill Peterson

Cultural Affairs, U.S. Department of State: "Outcome Assessment of the U.S. Fulbright Scholar Program." 2002, available at www.sri.com/policy/csted/reports/international/executive_report.pdf

${ }^{7}$ Dena S. Davis, "Why Academic Boycotts Are Wrong." The

Chronicle of Higher Education 49 (April 18, 2003). 